\title{
Risk factors related to cardiovascular complications in children diagnosed with Kawasaki disease in Northwestern Mexico
}

\author{
Olivia A. Flores-Montes ${ }^{1}$, Jaime Valle-Leal ${ }^{1 *}$, Roberto Arreguin-Reyes ${ }^{2}$, and Jesús M. Armenta-Velderrain ${ }^{1}$ \\ ${ }^{1}$ Departament of Pediatrics; ' $D$ Departament of Reumatology. Regional General Hospital \#1, Mexican Institute of Social Security, Obregón City, Sonora, \\ Mexico
}

\begin{abstract}
Background: Kawasaki disease $(K D)$ is an acute systemic vasculitis of small and medium vessels, which occurs primarily in children. Its clinical picture shows as a febrile syndrome combined with vasculitis that can cause coronary artery abnormalities in $25 \%$ of untreated patients. The objective of this study was to describe the clinical behavior and to identify risk factors for cardiovascular complications in pediatric patients with KD in the second level hospital in northwestern Mexico. Methods: Under a case series design, we studied pediatric patients with a diagnosis of KD. We measured clinical variables, laboratory values, and the presence of cardiac complications; the probability of risk was determined with an odds ratio (OR) and the association with the Chi-squared test. Results: A total of 12 patients were included in the study, in which the female gender predominated; the mean age of presentation of KD was 2 years. The clinical presentation was complete in $100 \%$ of the cases, and patients also presented atypical manifestations; $50 \%$ of the patients studied had cardiovascular complications, and the most common was the coronary disease (33\%). The variables male gender, age under 2 years, and anemia reported OR of 5.5-10 for suffering cardiovascular complications. Conclusions: Cardiovascular complications of KD are frequent (> 30\%). Male gender, age under 2 years, and anemia increase the risk of cardiovascular complications.
\end{abstract}

Key words: Kawasaki disease. Clinical behavior. Aneurysms. Myocarditis. Immunoglobulin.

\section{Factores de riesgo asociados a complicaciones cardiovasculares en pacientes con enfermedad de Kawasaki en el noroeste de México}

\section{Resumen}

Introducción: La enfermedad de Kawasaki (EK) es una vasculitis sistémica aguda de pequeños y medianos vasos, que se presenta principalmente en niños. Se manifiesta como síndrome febril aunado a datos de vasculitis, y puede causar anormalidades en las arterias coronarias en el $25 \%$ de los pacientes no tratados. El objetivo de este estudio fue describir el comportamiento clínico y la identificación de factores de riesgo para complicaciones cardiovasculares en pacientes pediátricos con EK atendidos en un hospital de segundo nivel del noroeste de México. Métodos: Bajo un diseño de serie de casos, se estudiaron pacientes pediátricos con diagnóstico de EK. Se midieron variables clínicas, de laboratorio y presencia

\section{Correspondence:}

Jaime Valle-Leal,

E-mail: valle_jaime1@ @otmail.com
Date of reception: 18-07-2017

Date of acceptance: 03-12-2017

DOI: 10.24875/BMHIME.M18000033
Available online: 14-11-2018

Bol Med Hosp Infant Mex. 2018;75:123-129

www.bmhim.com

2444-3409/@ 2018. Hospital Infantil de México Federico Gómez, published by Permanyer México SA de CV, all rights reserved. 
de complicaciones cardiacas, y se estimó la probabilidad de riesgo con razón de momios (RM) y asociación con prueba de ji al cuadrado. Resultados: Se incluyeron 12 pacientes y predominó el sexo femenino; la edad media de presentación de la EK fue de 2 años. La presentación clínica fue completa en el 100\% de los casos y hubo además manifestaciones típicas. El 50\% de los pacientes estudiados presentaron complicaciones cardiovasculares; la más común fue afección coronaria (33\%). Las variables sexo masculino, edad menor de 2 años y anemia tuvieron RM de 5.5 y 10 de presentar complicaciones cardiovasculares. Conclusiones: Las complicaciones cardiovasculares de la EK son frecuentes (más del 30\% de los pacientes). Las variables sexo masculino, edad menor de 2 años y anemia incrementaron la probabilidad de riesgo para la presencia de complicaciones cardiovasculares.

Palabras clave: Enfermedad de Kawasaki. Comportamiento clínico. Aneurismas. Miocarditis. Inmunoglobulina.

\section{Introduction}

Kawasaki disease $(K D)$ is an acute systemic vasculitis of small and medium vessels that occur mainly in children. It manifests as febrile syndrome combined with data of vasculitis and can cause abnormalities in the coronary arteries in $25 \%$ of untreated patients ${ }^{1-3}$. Its incidence is higher in children under 5 years old, and the highest number of cases occurs in the winter and spring seasons ${ }^{1-5}$.

The incidence of the disease is not well known. In Japan, 218 cases have been reported for every 100,000 children under 5 years old ${ }^{6}$; in the U.S., 20 cases per year per 100,000 children; and in some Latin American countries, 11 annual cases per 100,000 children under 5 years old. In Mexico, the actual incidence is not known since there is only a report of some series of cases of the disease $e^{4,7-11}$.

The etiology is not clearly defined, but it is believed that there are triggers in genetically susceptible individuals that precipitate the cascade of inflammatory events that give rise to the disease $\mathrm{e}^{12-16}$.

The absence of specific laboratory tests makes the diagnosis a clinical challenge. Therefore, it is based on the criteria proposed by Kawasaki, which were later confirmed by the American Heart Association (AHA) ${ }^{5}$. There are also supplementary laboratory criteria, which are not specific, but are useful when the patient has clinical characteristics that are suggestive, but not diagnostic, of the disease (incomplete) ) $^{5,17}$.

During the acute phase of the disease, there are infiltration and inflammation of cardiac cells that can generate coronary, myocardial, valvular, and pericardial affection. These alterations are presented in $>40 \%$ of patients ${ }^{2}$. Therefore, they must be intentionally evaluated with a two-dimensional echocardiogram, which should be performed at the time of diagnosis ${ }^{18}$.

Some predictors of coronary disease have been identified, such as an incomplete presentation of the disease, male sex, age younger than 1 year or older than 5 years, and fever for 6 days or longer. The Harada score identifies patients with $\mathrm{KD}$ and high risk of developing coronary aneurysms; this classification considers risk when the score is $\geq 42,4,5$.

The low clinical suspicion of the disease continues to delay the diagnosis and, with it, the increase in the risk of cardiovascular complications ${ }^{19}$. It is essential to know how the condition is expressed among different ages and different regions of the country. This study aimed to describe the clinical behavior and the recognition of risk factors for cardiovascular complications in pediatric patients with KD treated in the second level hospital in northwestern Mexico.

\section{Methods}

After the authorization by the local ethics and research committee, a case study was conducted with pediatric patients diagnosed with $\mathrm{KD}$, treated at the second level care hospital in northwestern Mexico, between January 2013 and July 2016. The variables studied were cardiovascular complications (present or absent and type of condition), clinical behavior (complete presentation, incomplete, and atypical manifestations), Harada score, sex, age, leukocyte count, hemoglobin $(\mathrm{Hb})$, mean corpuscular volume, platelet count, C-reactive protein (CRP), erythrocyte sedimentation rate (ESR), serum albumin values, erythrocyturia, pyuria, cylindruria, alanine aminotransferase (ALT), aspartate aminotransferase (AST), urea, creatinine, nutritional status (eutrophic, overweight, obesity, and severe obesity), season of the year in which the disease was diagnosed (spring, summer, autumn, or winter), treatment (adequate or inadequate), and proteinuria (positive or negative). A cell count $>15,000 / \mathrm{mm}^{3}$ was considered leukocytosis. A platelet count $>4,50,000 / \mathrm{mm}^{3}$ was considered as thrombocytosis. Anemia is defined as $\mathrm{Hb}$ level under 10 $\mathrm{g} / \mathrm{dL}$; hypoalbuminemia as albumin concentrations under $3 \mathrm{~g} / \mathrm{dL}$. Positive CRP, values > $1 \mathrm{mg} / \mathrm{dL}$; High ESR, serum values higher than $40 \mathrm{~mm} / \mathrm{h}$. Erythrocyturia as 
the presence of $\geq 5$ erythrocytes (RBC) per high power field in the urinary sediment; leukocyturia, as the presence of $>5$ leukocytes per high power field in urinary sediment; and ALT and AST, as serum values higher than $40 \mathrm{U} / \mathrm{l}$.

The disease was classified according to the clinical criteria of presentation: as complete KD when fever of $>5$ days of evolution persists and at least four of the following criteria: (1) changes in the extremities; (2) polymorphic rash; (3) bilateral bulbar conjunctival injection without exudate; (4) changes in the lips and oral cavity; and (5) acute non-purulent lymphadenopathy. If $<4$ criteria are met, and coronary alterations are detected in the echocardiogram, it is considered as incomplete $\mathrm{KD}$. If the patients presented renal changes (proteinuria, erythrocyturia, cylindruria, leukocyturia, sterile pyuria, and elevated nitrogen compounds), gastrointestinal alterations (diarrhea, vomiting, and abdominal pain), hepatic alterations (hyperbilirubinemia, hypertransaminasemia, and hypoalbuminemia), or neurological alterations (extreme irritability, aseptic meningitis, and neurosensory loss), these were classified as atypical or uncommon manifestations.

The extent of the fever (in days) was also assessed, as well as cardiovascular complications integrated by echocardiography (coronary dilatation with an internal diameter $>2.5 \mathrm{~mm}$, small coronary aneurysm if measured $<5 \mathrm{~mm}$, medium between 5 and $8 \mathrm{~mm}$, and giant if measured $>8 \mathrm{~mm}$ ). Furthermore, the treatment received and the time of evolution of the disease in which it was administered, as well as the Harada score of each of the patients to estimate the risk of developing coronary aneurysms.

According to the treatment, the administration of salicylates, glucocorticoids, and immunoglobulin was considered, dividing the latter into three groups: (1) early administration, those who received $2 \mathrm{~g} / \mathrm{kg}$ in continuous infusion of $12 \mathrm{~h}$ before 10 days of evolution, (2) late administration, who received $2 \mathrm{~g} / \mathrm{kg}$ after 10 days of evolution, and (3) those who did not receive immunoglobulin or in whom the dose was fractionated.

Data collected were transferred to an electronic database and analyzed using the Statistical Package for Social Science version 2.0. Descriptive statistics were used. The qualitative variables were described in measures of frequency (percentages), medians and interquartile ranges for quantitative variables, and determination of the odds ratio (OR) RM to determine the risk. The $\chi^{2}$ test determined the association between qualitative variables.
Table 1. General description of pediatric patients $(n=12)$ with Kawasaki disease treated in the second level care hospital in Northwestern Mexico

\begin{tabular}{|c|c|}
\hline Variable & Frequency (\%) \\
\hline $\begin{array}{l}\text { Sex } \\
\text { Female } \\
\text { Male }\end{array}$ & $\begin{array}{l}8 / 12(67) \\
4 / 12(33)\end{array}$ \\
\hline $\begin{array}{l}\text { Age (years) } \\
<2 \\
\geq 2\end{array}$ & $\begin{array}{l}4 / 12(33) \\
8 / 12(67)\end{array}$ \\
\hline $\begin{array}{l}\text { Nutritional status } \\
\text { Eutrophic } \\
\text { Overweight and obesity }\end{array}$ & $\begin{array}{l}5 / 12(42) \\
7 / 12(58)\end{array}$ \\
\hline $\begin{array}{l}\text { Season } \\
\text { Spring } \\
\text { Summer } \\
\text { Fall } \\
\text { Winter }\end{array}$ & $\begin{array}{l}4 / 12(34) \\
1 / 12(8) \\
1 / 12(8) \\
6 / 12(50)\end{array}$ \\
\hline $\begin{array}{l}\text { Phase } \\
\text { Acute } \\
\text { Subacute }\end{array}$ & $\begin{array}{l}8 / 12(66.6) \\
4 / 12(33.3)\end{array}$ \\
\hline $\begin{array}{l}\text { Clinical behavior } \\
\text { Complete } \\
\text { Incomplete }\end{array}$ & $\begin{array}{c}12 / 12(100) \\
0 / 12(0)\end{array}$ \\
\hline $\begin{array}{l}\text { Duration of fever (days) } \\
<10 \\
\geq 10\end{array}$ & $\begin{array}{l}6(50) \\
6(50)\end{array}$ \\
\hline $\begin{array}{l}\text { Extra mucocutaneous manifestations } \\
\text { Missing } \\
\text { Presents }\end{array}$ & $\begin{array}{c}12 / 12(100) \\
0 / 12(0)\end{array}$ \\
\hline $\begin{array}{l}\text { Treatment with intravenous immunoglobulin } \\
\text { Adequate } \\
\text { Unsuitable }\end{array}$ & $\begin{array}{l}10 / 12(83) \\
2 / 12(17)\end{array}$ \\
\hline $\begin{array}{l}\text { Cardiovascular complications } \\
\text { Left coronary lesion } \\
\text { Right coronary lesion } \\
\text { Coronary aneurysm } \\
\text { Left ventricle hypertrophy }\end{array}$ & $\begin{array}{l}2 / 12(17) \\
1 / 12(18) \\
1 / 12(18) \\
2 / 12(17)\end{array}$ \\
\hline
\end{tabular}

\section{Results}

We studied 12 patients, eight females and four males (ratio 2:1), whose median age was 2.05 years; four (33\%) patients were under 2 years old, and eight (67\%) were between 2 and 3.5 years (Table 1).

Regarding the phase of the disease at the time of diagnosis, eight patients $(67 \%)$ were diagnosed in the acute phase and four (33\%) in the subacute phase. The spell of the fever was variable, with a median of 9.5 days. The fever lasted 10 or more days in six $(50 \%)$ of the cases $^{6}$ (Table 1).

The clinical behavior at the time of diagnosis was complete KD in $100 \%$ of the cases; also, all presented 
Table 2. Typical and atypical (not common) manifestations in pediatric patients $(n=12)$ with Kawasaki's disease treated in the second level hospital in Northwest Mexico

\begin{tabular}{|c|c|}
\hline Typical manifestations & Frequency (\%) \\
\hline Fever $>10$ days & $8 / 12(67)$ \\
\hline Scaliness & $9 / 12(75)$ \\
\hline Exanthema & $11 / 12$ (92) \\
\hline Conjunctival hyperemia & $10 / 12(83)$ \\
\hline Oral hyperemia & $10 / 12(83)$ \\
\hline Adenopathies & $9 / 12(75)$ \\
\hline Oral bleeding & $6 / 12(50)$ \\
\hline Atypical manifestations & \\
\hline $\begin{array}{l}\text { Respiratory } \\
\text { Rhinorrhea } \\
\text { Cough } \\
\text { Respiratory difficulty } \\
\text { Pleural effusion }\end{array}$ & $\begin{array}{c}6 / 12(50) \\
6 / 12(50) \\
2 / 12(17) \\
1 / 12(8)\end{array}$ \\
\hline $\begin{array}{l}\text { Gastrointestinal } \\
\text { Abdominal pain } \\
\text { Diarrhea } \\
\text { Bleeding digestive tract }\end{array}$ & $\begin{array}{l}7 / 12(58) \\
5 / 12(42) \\
3 / 12(25)\end{array}$ \\
\hline $\begin{array}{l}\text { Renal } \\
\text { Hematuria } \\
\text { Proteinuria } \\
\text { Acute kidney injury }\end{array}$ & $\begin{array}{l}3 / 12(25) \\
3 / 12(25) \\
2 / 12(17)\end{array}$ \\
\hline $\begin{array}{l}\text { Articular } \\
\text { Arthritis } \\
\text { Arthralgias }\end{array}$ & $\begin{array}{l}3 / 12(25) \\
5 / 12(42)\end{array}$ \\
\hline $\begin{array}{l}\text { Cardiovascular } \\
\text { Myocarditis } \\
\text { Arterial hypertension }\end{array}$ & $\begin{array}{c}2 / 12(17) \\
1 / 12(8)\end{array}$ \\
\hline $\begin{array}{l}\text { Hepatic } \\
\text { Hepatomegaly } \\
\text { Hypertransaminasemia } \\
\text { Hyperbilirubinemia } \\
\text { Gallbladder hydrops }\end{array}$ & $\begin{array}{l}3 / 12(25) \\
5 / 12(42) \\
3 / 12(25) \\
1 / 12(8)\end{array}$ \\
\hline
\end{tabular}

atypical manifestations (also called uncommon) (Table 1). Table 2 describes the typical and atypical clinical signs found in this group of patients.

Laboratory abnormalities found most frequently were leukocytosis in $75 \%$ of patients, thrombocytosis in $67 \%$, and hypoalbuminemia and elevated AST in $50 \%$ of patients. Regarding the analysis of urinary sediment, $33.3 \%$ of the patients presented hyaline cylinders, $25 \%$ proteinuria, pyuria, and erythrocyturia, and $16.6 \%$ granular cylinders.

About the treatment, 10 patients (83\%) were given an adequate treatment, of which three were given the
Table 3. Description of pediatric patients with Kawasaki disease and cardiovascular complications $(n=6)$ treated in the second level hospital in Northwest Mexico

\begin{tabular}{|l|c|}
\hline Variable & Frequency (\%) \\
\hline Sex & \\
$\quad$ Male & $3 / 6(50)$ \\
Female & $3 / 6(50)$ \\
\hline Age & \\
$\quad<2$ years & $3 / 6(50)$ \\
$\quad 22$ years & $3 / 6(50)$ \\
\hline Nutritional status & \\
\hline Eutrophy & $2 / 6(33)$ \\
Overweight and obesity & $4 / 6(67)$ \\
\hline Atypical manifestations & \\
\hline Present & $6 / 6(100)$ \\
\hline Harada score & \\
Positive & $1 / 6(17)$ \\
\hline Fever extent & \\
\hline 10 days & $3 / 6(50)$ \\
\hline 10 days & $3 / 6(50)$ \\
\hline Treatment & \\
\hline Adequate & \\
\hline Inadequate & $4 / 6(67)$ \\
\hline
\end{tabular}

second dose of immunoglobulin for the persistence of fever. The 12 patients were given salicylates, and only one received glucocorticoids.

Cardiovascular complications were found in six $(50 \%)$ of the patients, three (3/8) females and three (3/4) males. Table 3 describes in detail the characteristics of this group of patients.

Of the patients with cardiovascular complications, the coronary disease was found in four (67\%): two presented dilation of the left coronary artery and one of the right coronary artery, and one presented aneurysm in both coronary arteries of medium size.

Table 4 shows the association of some laboratory alterations with the presence of cardiovascular complications; stand out erythrocyturia and anemia, with a probability (p) of 0.09 and 0.12 , respectively. The risk for cardiovascular complications was estimated, and an OR of 10 was determined for anemia; for ages under 2 years, male sex and presence of hyaline cylinders, an OR of 5 was determined (Table 4).

Table 5 describes the medians and interquartile ranges for age, days of fever, and laboratory results in patients with and without cardiovascular complications; the average of $\mathrm{Hb}$ was 9.5 in patients with complications versus 11.25 in patients without complications. 
Table 4. Association of alteration of biochemical parameters and risk estimation for cardiovascular complications in pediatric patients with Kawasaki disease $(n=12)$ treated in the second level hospital in Northwest Mexico

\begin{tabular}{|c|c|c|c|c|c|}
\hline & With complication (\%) & Without cardiovascular complication (\%) & p & OR & $95 \%$ CI \\
\hline $\mathrm{ESR}>40 \mathrm{~mm} / \mathrm{h}$ & $4 / 9(44)$ & $5 / 9(56)$ & 0.50 & 0.6 & $(0.2-1.9)$ \\
\hline $\mathrm{CRP}>1 \mathrm{mg} / \mathrm{dl}$ & $4 / 7(57)$ & $3 / 7(43)$ & 0.28 & 2 & $(0.56-7)$ \\
\hline Anemia & $5 / 7(71)$ & 2/7 (29) & 0.12 & 10 & $(0.6-154)$ \\
\hline Leukocytosis & $2 / 6(67)$ & $1 / 6(33)$ & 0.50 & 1.5 & $(0.5-4.4)$ \\
\hline Thrombocytosis & $4 / 6(67)$ & $4 / 6(67)$ & 1 & 1 & $(0.3-3.3)$ \\
\hline Urea elevated & $2 / 3(57)$ & $1 / 3(33)$ & 0.50 & 2.5 & $(0.1-38)$ \\
\hline Elevated creatinine & $3 / 5(60)$ & $2 / 5(40)$ & 0.50 & 2 & $(0.1-20)$ \\
\hline Hypoalbuminemia & $4 / 6(67)$ & $2 / 6(33)$ & 0.28 & 4 & $(0.3-44)$ \\
\hline Elevated ALT & $3 / 5(60)$ & $2 / 5(40)$ & 0.55 & 2 & $(0.2-20)$ \\
\hline Elevated AST & $3 / 6(50)$ & $3 / 6(50)$ & 1 & 1 & $(0.1-9.6)$ \\
\hline Hyperbilirubinemia & $2 / 3(67)$ & $1 / 3(33)$ & 0.50 & 2.5 & $(0.1-38)$ \\
\hline Proteinuria & $2 / 6(67)$ & $1 / 6(33)$ & 0.13 & 1.5 & $(0.5-4.4)$ \\
\hline Erythrocyturia & $3 / 3(100)$ & $0(0)$ & 0.09 & - & - \\
\hline Hyaline cylinders & $3 / 4(75)$ & $1 / 4(25)$ & 0.27 & 5 & $(0.3-72)$ \\
\hline Granular cylinders & $2 / 2(100)$ & $0(0)$ & 0.22 & - & - \\
\hline Leukocyturia & $2 / 3(67)$ & $1 / 3(33)$ & 0.50 & 2.5 & $(0.1-38)$ \\
\hline Fever $>10$ days & $3 / 6(50)$ & $1 / 6(17)$ & 0.22 & 2 & $(0.6-5.7)$ \\
\hline Overweight and obesity & $4 / 6(67)$ & $2 / 6(33)$ & 0.34 & 1.4 & $(0.4-4.9)$ \\
\hline Male & $3 / 4(75)$ & $1 / 4(25)$ & 0.27 & 5 & $(0.7-72)$ \\
\hline Female & $3 / 8(38)$ & $5 / 8(62)$ & 0.27 & 0.2 & $(0.01-2)$ \\
\hline Age $<2$ years & $3 / 4(75)$ & $1 / 4(25)$ & 0.27 & 5 & $(0.7-72)$ \\
\hline Age $\geq 2$ years & $3 / 8(38)$ & $5 / 9(62)$ & 0.27 & 0.2 & $(0.01-2)$ \\
\hline
\end{tabular}

ALT: alanine aminotransferase; AST: aspartate aminotransferase; Cl: confidence interval; CRP: C-reactive protein; OR: odds ratio; ESR: erythrocyte sedimentation rate, p: probability calculated by Fisher's exact test.

\section{Discussion}

In this study, the predominance of female sex was found, with a male:female ratio of 1:2, different from that reported by Sotelo-Cruz ${ }^{2}$, who found a predominance of male sex in a 3.3:1 ratio. Cases were more frequent in children under 2 years old, different from that reported by national series in which patients between 3 and 5 years of age predominated ${ }^{2,3,20}$.

According to the season, half of the cases took place in winter and only one-third in spring, which differs from that reported in national studies, in which a higher frequency of cases was determined in the spring ${ }^{3}$.

The majority of patients were detected during the acute phase, with an average fever of 9.5 days, which is similar to that reported by Morales-Quispe et al. ${ }^{20} \mathrm{It}$ is very close to the limit of what is recommended by the AHA to reduce the risk of coronary complications ${ }^{7}$.

Regarding clinical behavior, all patients met the criteria to define complete $K D$, similar to that found in the most extensive series published in Mexico ${ }^{2,6,11}$. Similarly, all the patients presented atypical manifestations, a higher proportion than that reported in other series $^{2,3,6,9,20,21}$. The most common atypical (uncommon) symptoms were gastrointestinal (abdominal pain and diarrhea), respiratory (cough), and joint aching (arthralgias), similar to Sotelo-Cruz ${ }^{2}$, who found a predominance of joint pain, hepatomegaly, cough, abdominal pain, nausea, and vomiting. 
Table 5. Description of medians and interquartile ranges of clinical and laboratory characteristics of pediatric patients with Kawasaki disease with and without cardiovascular complications $(n=12)$

\begin{tabular}{|l|c|c|}
\hline & With cardiovascular complication & Without cardiovascular complication \\
\cline { 2 - 3 } & Median (IOR) & Median (IOR) \\
\hline Age (years) & $1.7(1.9)$ & $2.15(0.9)$ \\
\hline Fever (days of duration) & $12(9)$ & 8 (3) \\
\hline ESR (mm/h) & $46(8)$ & $47.5(5)$ \\
\hline C-reactive protein (mg/dL) & $1.25(0.5)$ & $1.05(0.3)$ \\
\hline Hb (g/L) & $9.6(0.8)$ & $11.25(1.6)$ \\
\hline Average corpuscular volume (fl) & $82(9)$ & $90(5)$ \\
\hline Leukocytes (leukocytes/mm 3 ) & $12,700(6180)$ & $10,100(2700)$ \\
\hline Platelets (platelets/mm $\left.{ }^{3}\right)$ & $495,500(341,000)$ & $415,000(174,000)$ \\
\hline Urea (mg/dL) & $20.5(22)$ & $22(18)$ \\
\hline Creatinine (mg/dL) & $0.65(0.5)$ & $0.45(0.5)$ \\
\hline Albumin g/dL & $2.7(0.9)$ & $3.3(0.7)$ \\
\hline ALT (U/L) & $52.5(30)$ & $40.5(22)$ \\
\hline AST (U/L) & $47.5(53)$ & $40(9)$ \\
\hline Total bilirubin (mg/dL) & $0.95(0.7)$ & $0.4(0.4)$ \\
\hline
\end{tabular}

ALT: alanine aminotransferase; AST: aspartate aminotransferase; IQR: interquartile range; ESR: erythrocyte sedimentation rate, Hb: hemoglobin

The most frequent laboratory alterations were leukocytosis, thrombocytosis, hypoalbuminemia, and elevated AST, which have been observed in the majority of published studies. CRP was elevated in all patients, but in all cases it was under $3 \mathrm{mg} / \mathrm{dL}$.

All patients received intravenous immunoglobulin $(2 \mathrm{~g} / \mathrm{kg})$. Most of them received adequate treatment with early immunoglobulin and salicylates; only two patients received late immunoglobulin treatment and one patient required glucocorticoid for the fever persistence. These three patients presented coronary alterations, which are related to that reported by Garrido-García et al. ${ }^{6}$ In that series of cases, patients who received intravenous immunoglobulin after day 10 of evolution and the one who received glucocorticoids presented coronary alterations; two patients showed coronary dilation, and one, an aneurysm of both coronary arteries. Of these, only the one that received glucocorticoids presented a positive Harada score. Furthermore, $50 \%$ of the patients in this series presented echocardiography alterations, percentage higher than the $32 \%$ reported by Sotelo-Cruz ${ }^{2}$, the $29.4 \%$ reported by García-Rodríguez et al. ${ }^{11}$, and the $35 \%$ reported by Surjit et al. ${ }^{22}$ However, it was similar to the $54 \%$ reported by Gil-Veloz et al. ${ }^{3}$ Our results may have been influenced by the characteristics of the patients in our series since there is female predominance, the median age is 2.1 years (lower than that reported in other series), ${ }^{2,3,20}$ and there is a high frequency of atypical manifestations.

Of the patients with echocardiographic alterations, $50 \%$ were female. However, more cardiovascular complications were observed in males $(75 \%)$ than in females $(38 \%)$. Regarding age, $50 \%$ of the patients with cardiovascular complications were younger than 2 years; the other $50 \%$ was between 2 and 3.5 years old.

Within the laboratory parameters, a 10-time higher risk of developing cardiovascular complications was found in patients who had anemia, and 5 times higher in male patients with hyaline cylinders in the urinary sediment and those under 2 years of age. Elevation of CRP and ESR, a leukocyte count $>12,000$, low $\mathrm{Hb}$ values, a hematocrit of $<35 \%$, decreased serum albumin, elevated transaminases, and hyponatremia have been reported in other publications as risk factors for presenting cardiovascular complications ${ }^{23}$.

The median $\mathrm{Hb}$ in patients with cardiovascular complication was 9.6 versus 11.25 in patients without complications. These results are similar to those by Caballero-Mora et al. ${ }^{23}$, who reported a mean $\mathrm{Hb}$ of 10.3 in patients with complications and 11.42 in patients without 
complications. The median number of days of fever was 12 for patients with cardiovascular complications versus 8 days for patients without cardiovascular complications.

Early detection is crucial to avoid cardiovascular complications. In this series, most patients were adequately treated, and cardiovascular complications occurred in half of the cases: $33 \%$ corresponded to coronary disease, similar to that reported in other national series. ${ }^{3,6}$ In Japan, a decrease in cardiovascular consequences (coronary aneurysms and myocardial infarctions) has been observed thanks to the detection during the acute phase of the disease and its adequate management ${ }^{9}$. As reported by Gil-Veloz et al. ${ }^{3}$ and Morales-Quispe et al. ${ }^{20}$, the early administration of gamma-globulin during the first day of the disease reduces the risk of cardiovascular complications, especially residual aneurysms.

Although the risk of erythrocyturia for the development of cardiovascular complications has not been reported, as was found in our study, the association of this sign or others should be studied further in more extensive series of patients to improve the prediction of risk complications and timely treatment.

Furthermore, the classification according to the criteria of the AHA is limiting since the frequency of atypical or incomplete course is high, as observed in this series and other reports ${ }^{24}$. Therefore, the classification of the disease according to standard criteria results problematic.

The variability in the presentation of the symptoms requires a more significant number of research studies that allow knowing how the disease manifests under different sociodemographic and geographical conditions.

We recognize limitations on our study because there are possibilities of affecting the information contained in the files despite the efforts to overcome the selection and information biases. Besides, the sample size is small, which weakens the power of the statistical analysis. Multicenter studies are suggested for larger samples, with robust statistical analysis and the possibility of generalization of the results.

\section{Ethical disclosures}

Protection of human and animal subjects. The authors declare that no experiments have been conducted on humans or animals for this research.

Confidentiality of data. The authors declare that they have followed the protocols of their work center on the publication of patient data.

Right to privacy and informed consent. The authors have obtained the informed consent of the patients and subjects referred to in the article.

\section{Conflicts of interest}

The authors declare no conflicts of interest.

\section{References}

1. Jamieson N, Singh-Grewal D. Kawasaki disease: a clinician's update. Int J Pediatr. 2013;2013:1-7.

2. Sotelo-Cruz N. Revisión de la enfermedad de Kawasaki en México, desde la perspectiva de las publicaciones médicas (enero de 1977 a mayo de 2012). Arch Cardiol Mex. 2013;83:214-22.

3. Gil-Veloz M, Flores-Ruiz EM, Beirana-Palenciana LG, Miranda-Novales MG, Huerta-García GC, Solórzano-Santos F. Enfermedad de Kawasaki: comportamiento clínico y complicaciones cardiovasculares en niños atendidos en un hospital de tercer nivel. Arch Cardiol Mex. 2009;79:11-7.

4. Burns JC. Commentary: translation of Dr. Tomisaku Kawasaki's original report of fifty patients in 1967. Pediatr Infect Dis J. 2002;21:993-5.

5. Kawasaki T. [Acute febrile mucocutaneous syndrome with lymphoid involvement with specific desquamation of the fingers and toes in children]. Arerugi. 1967;16:178-222.

6. Garrido-García LM, Soto-Blanquel JL, Espinosa-Rosales FJ. Enfermedad de Kawasaki: cuadro clínico, exámenes de laboratorio y lesiones coronarias. Acta Pediatr Mex. 2015;36:314-21.

7. Newburger JW, Takahashi M, Gerber MA, Gewitz MH, Tani LY, Burns JC, et al. Diagnosis, treatment, and long-term management of Kawasaki disease: a statement for health professionals from the committee on rheumatic fever, endocarditis, and Kawasaki disease, council on cardiovascular disease in the Young, American Heart Association. Circulation. 2004; $110: 2747-71$

8. Centers for Disease Control and Prevention. Kawasaki syndrome. USA: Department of Health \& Human Services; 2013. Available at: http://www. cdc.gov/kawasaki

9. Makino N, Nakamura Y, Yashiro M, Ae R, Tsuboi S, Aoyama Y, et al. Descriptive epidemiology of Kawasaki disease in Japan, 2011-2012: from the results of the $22^{\text {nd }}$ nationwide survey. J Epidemiol. 2015;25:239-45.

10. Newburger JW, Taubert KA, Shulman ST, Rowley AH, Gewitz MH, Takahashi M, et al. Summary and abstracts of the seventh international Kawasaki disease symposium: december 4-7, 2001, Hakone, Japan. Pediatr Res. 2003:53:153-87.

11. García-Rodríguez F, Flores-Pineda AJ, Villareal-Treviño AV, Salinas-Encinas DR, Lara-Herrera PB, Maldonado-Velásquez MR, et al. Enfermedad de Kawasaki en un hospital pediátrico en México. Bol Med Hosp Infant Mex. 2016;73:166-73.

12. Yeung RS. Kawasaki disease: update on pathogenesis. Curr Opin Rheumatol. 2012;22:551-60.

13. Rowley $\mathrm{AH}$. Kawasaki disease: novel insights into etiology and genetic susceptibility. Annu Rev Med. 2011;62:69-77.

14. Rowley AH, Shulman ST. Pathogenesis and management of Kawasaki disease. Expert Rev Anti Infect Ther. 2012;8:197-203.

15. Rowley A, Schulman S. Recent advances in the understanding and management of Kawasaki disease. Curr Infect Dis Rep. 2010;12:96-102.

16. Onouchi Y, Gunji T, Burns JC, Shimizu C, Newburger JW, Yashiro M, et al. ITPKC functional polymorphism associated with Kawasaki disease susceptibility and formation of coronary artery aneurisms. Nat Genet. 2008;40:35-42.

17. Rowley A. The complexities of the diagnosis and management of Kawasaki disease. Infect Dis Clin North Am. 2015;29:525-37.

18. Yutani $\mathrm{C}, \mathrm{Go} \mathrm{S}$, Kamiya T, Hirose O, Misawa H, Maeda H, et al. Cardiac biopsy of Kawasaki disease. Arch Pathol Lab Med. 1981;105:470-3.

19. Sundel RP. Kawasaki disease. Rheum Dis Clin North Am. 2015:41:63-73.

20. Morales-Quispe JA, Espínola-Zavaleta N, Caballero-Caballero R, García-López JJ, Rodríguez-Quezada JM, Betanzos-Rodríguez E. Enfermedad de Kawasaki: evolución y complicaciones cardiovasculares en niños. Rev Med Inst Mex Seguro Soc. 2011;49:295-300.

21. Sotelo N, González LA. Kawasaki disease: a rare pediatric pathology in Mexico. Twenty cases report from the Hospital Infantil del Estado de Sonora. Arch Cardiol Mex. 2007;77:299-307.

22. Surjit S, Sikha A, Sagar B, Anju G, Deepti S, Amit R, et al. Kawasaki disease in infants below 6 months: a clinical conundrum? Int J Rheum Dis. 2016;19:924-8.

23. Caballero-Mora FJ, Alonso-Martín B, Tamariz-Martel-Moreno A, Cano-Fernández J, Sánchez-Bayle M. Enfermedad de Kawasaki en 76 pacientes. Factores de riesgo de aparición de aneurismas coronarios. An Pediatr (Barc). 2011;74:232-8.

24. Sotelo-Cruz N. Curso atípico o incompleto de la enfermedad de Kawasaki en edades pediátricas. Bol Med Hosp Infant Mex. 2016;73:147-8. 